two similar receivers, the front one of which is exposed to the radiation. The target consists of a massive copper disk $4.5 \mathrm{~cm}$. in diameter and $0.5 \mathrm{~cm}$. thick to ensure temperature uniformity. Thermocouples are attached at a number of points in order to average the rise in temperature. The electrical heating element is cemented to the front disk on the side exposed to the radiation. The cycle of operations and the practice carried out in the Laboratory for the calibration of working-standard thermopiles against the Guild radiometer with a radiation source, consisting of a 1,000-W. tungsten lamp operated at a colour temperature of $2,850^{\circ} \mathrm{K}$., together with water filter and heat-absorbing glass to absorb radiation of a wave-length longer than $1 \mu$, are explained in detail.

The second booklet, No. 24 (ref. 2), is concerned with photometric standards and the unit of light. The development of light sources from the early nineteenth century and the evolution of the present primary standard, with the internationally accepted unit of luminous intensity, the candela, are discussed, followed by a detailed description of the procedures carried out at the National Physical Laboratory with regard to the arrangement of the primary standard, ond calibration of secondary standards of luminous intensity and luminous flux. Finally, the present international situation with regard to intercomparisons of photometric scales is reviewed, and a table is given showing the relative magnitudes of the candela $\left(2,042^{\circ} \mathrm{K}\right.$.) as found in the most recent determinations (up to 1957) at various national laboratories. The monograph can be recommended as a comprehensive and instructive statement of photometric standards and light sources, and should be of value to all concerned with illumination. S. WEINTrouB

${ }^{1}$ Department of Scientific and Industrial Research: National Physical Laboratory. Notes on Applied Science, No. 23: Radiometric Standards and Mecsurements. F. J Gillham. $\mathrm{Pp}$. iv +23 , (London: H.M.S.O., 1961.) 18. $9 d$. net.

2 Department of Scientifle and Industrial Research: National Physical Laboratory. Nutes on Applied Science No. 24: Photometric Standards and the Unit of Light. J. S. Preston. Pp. iv +32+ 4 plates. (London: H.M.S.O., 1961.) 38 . net.

\title{
GEOLOGY OF BROWN CLEE HILL AND THE ADJACENT AREA
}

\begin{abstract}
THE Old Red Sandstone of Brown Clee Hill and the Adjacent Area*, recently issued by the British Museum (Natural History), is an important paper as it deals with a classic area in which is displayed the most complete sequence of Old Red deposits of the Anglo-Welsh development. In the first quarter of the century Wickham King established a general stratigraphical succession for that development, which he based to a large extent on his findings in the Brown Clee district, but his support ing palæontological evidence was too meagre and scattered to provide really convincing fossil zones. At that time too many of the forms had been inadequately described or named from fragments. King's work, however, generated a stimulus that has led to a revolution in our knowledge of the British Old Red ostracoderm faunas. This has been the result of systematic collecting and accurate description. The latter we owe chiefly to the senior author, Dr. E. I. White, and Part 2 of the present paper is his latest contribution to the subject. While our knowledge of the fossils has been gradually accumulating, the palæontologist has had, to a great extent, to rely on King's stratigraphical conclusions, which were not always based on reliable mapping.
\end{abstract} * Bulletin of the British Museum (Natural History). Geology.
Vol. 5, No. 7: The Old Red Sandstone of Brown Clee Hill and the Vol. 5, No. 7: The Old Red Sandstone of Brown Clee Hill and the Adjacent Area. 1: Stratigraphy. By Harold William Ball and David Lawrence Dineley. 2: Palæontology By Errol Ivor White. Pp 1961.) 70 s.
In the present case the two junior authors have presented an excellent map based on accurate 6 -in. survey and elaborate collecting, which have enabled them to determine the range of the fossils with considerable accuracy. For the Downtonian Series, they have taken advantage of much recent palæontological work; and the zones for this series can now be regarded as well established, and their evidence as merely confirming conclusions reached previously in this and other areas. But for the desperately barren Dittonian and Clee Series, their painstaking fie'd-work has supplied Dr. White with material, by which broad zones can now be defined with some exactness.

Part 1, devoted to the stratigraphy, includes interesting discussions concerning the geographical conditions governing sedimentation, the ecology of the fossiliferous 'pockets', the so-called Psammosteus Limestone (which has never yielded a fossil, let alone a Psammosteus), and foreign pebbles in the conglomerates; but its main significance is the correlation of the fossils with the stratal succession, and the determination of the range of each important species. A valuable feature is a list of more than a hundred localities with the fauna discovered at each.

Part 2 is descriptive of a number of new species and varieties illustrated by 60 text figures and 16 plates. Of particular value are the new forms discovered by the authors and others in the Clee Series and in the unconformable upper Old Red beds (the Farlow Sandstone Series).
L. J. WILLS

\section{FIRE RESEARCH 1960}

$\mathrm{T}$ HE recently issued annual report of the Joint Fire Research Organization * records the bringing into use, during 1960 , of new buildings providing $30,000 \mathrm{sq}$. ft. of permanent floor area for the continued prosecution of fire research (see Nature, 189, 105; 1961).

* Department of Scientific and Industrial Research and Fir Offices' Committee Joint Fire Research Organization. Fire Research, 1960: Report of the Fire Research Board with the Report of the Director of Fire Research. Pp. viii $+67+12$ plates. (London: H.M.S.O., 1961.) 58. 6 d. net.
Among the many investigations described, that which focused attention on the behaviour in draughts of oil heaters of the drip-feed radiant type has doubtless aroused the greatest public interest. The relatively new and unique wind-tunnel facilities of the Fire Research Station permitted an expeditious study of this problem, followed, within the year under review, by the publication of a report and a new British Standard and, finally, by the introduction of appropriate legislation. 